\title{
Fabian Mauch
}

\section{Romantic Nationalism and German "Universality". Novalis' Europa Speech and its context}

\author{
Romantischer Nationalismus und deutsche „Universalität“. Novalis” \\ „Europa“-Rede und ihr Kontext
}
Romantyczny nacjonalizm i niemiecki uniwersalizm. „Europa” Novalisa, praca i jej kontekst
Keywords: "Christendom or Europe", nationalism, Novalis (Friedrich von Hardenberg), Reformation, Romanticism
Schlüsselwörter: Christentum oder Europa“, Nationalismus, Novalis (Friedrich von Hardenberg), protestantische Reformation, Romantik

Słowa kluczowe: „Chrześcijaństwo, czyli Europa”, nacjonalizm, Novalis (Friedrich von Hardenberg), reformacja, romantyzm

\begin{abstract}
The poet Novalis (Friedrich von Hardenberg) first put forward the idea that the German nation was destined to "deliver" Europe from its political and cultural crisis, an idea that formed the basis of his work "Europe" (1799). With it he ultimately transferred Christian universalism and missionarism into politics, thereby establishing a line of thinking that German nationalism would lastingly incorporate into its mindset.
\end{abstract}

\section{ZUSAMMENFASSUNG}

Der Dichter Novalis (Friedrich von Hardenberg) entwickelte als erster die Vorstellung, dass es die „Mission“ der Deutschen sei, Europa von seiner politischen und kulturellen Krise zu „erlösen“. Die Idee bildete den Kerngedanken seiner „Europa“-Rede (1799). Mit ihr übertrug er letztlich den christlichen Universalismus und Missionarismus auf das Politische, womit er 
eine Denktradition begründete, die zu einem festen Bestandteil des deutschen Nationalismus werden sollte.

\section{STRESZCZENIE}

Poeta Novalis (Friedrich von Hardenberg) jako pierwszy wysunął ideę, że przeznaczeniem narodu niemieckiego jest „wyzwolenie” Europy z jej politycznego i kulturowego kryzysu, ideę, która stała się podstawą jego dzieła pt. „Europa” (1799). W pracy tej przeniósł on chrześcijański uniwersalizm i misyjność na politykę, ustanawiając sposób myślenia, który miał się stać integralną częścią niemieckiego nacjonalizmu.

The emergence of the modern nation-state is commonly associated with the French Revolution, which fundamentally reshaped the structure of European politics. In consequence, no longer kings or dynasties but peoples were viewed as the primary subjects of the political process. This empowerment of the "nation" was based on the concept of "popular sovereignty" as emphasised in the Declaration of the Rights of Man and the Citizen. German nationalism, in reaction, borrowed a great many ideas and concepts from the French Revolution, which it adopted and adjusted to its own special conditions, that often differed, however, greatly from those in France. Since the Holy Roman Empire was no unitary state and consisted of several sovereign and semi-sovereign kingdoms and principalities, German "nation-building" primarily involved the construction of an all-German identity as basis for any national movement. As there was no political frame from which such an identity could be derived, German intellectuals instead drew on the concept of a religious or cultural identity (Kulturnation), a concept that was eventually used to justify a German nationalism not primarily based on the principle of "popular sovereignty" but on the assumed superiority of German culture. In the end, this culture nationalism proved to be barely less expansionary and missionary than its French role model, even if its expansionism and missionarism were not primarily political (although they could be instrumentalised in such a way, of course).

It was, in fact, no other than the poet Novalis (Friedrich von Hardenberg) who as early as 1798 - first brought forth the idea, that the German nation was predestined to "deliver" Europe from its political and cultural crisis. It was his belief, that, since the French Revolution had failed to provide a satisfactory answer to this crisis, it had become Germany's task to supply Europe with a new cultural model, as it had done 300 years earlier with the Protestant Reformation. This idea formed the pivotal basis of his so-called Europa Speech (1799), which in many respects marks the climax of his political philosophy.

The text nowadays known as Christendom or Europe (Die Christenheit oder Europa $)^{1}$ was most likely written during the autumn of 1799 and formed the basis for the

\footnotetext{
The title came not from Novalis himself. It dates from the first printing in the fourth edition of Novalis
} 
speech Novalis delivered on the $13^{\text {th }}$ or $14^{\text {th }}$ of November of that same year before an audience of friends and acquaintances in Jena. ${ }^{2}$ The speech, as can be inferred from the remarks of the hearers, was not all too well received. Objections were especially raised against Novalis' seemingly positive perception of Catholicism. ${ }^{3}$

Of course, Novalis did not actually propose a return to pre-Reformatory Catholicism. In his eyes the rule of the Catholic church had, due to the vulgarity and baseness of its thinking, already ceased long before the forceful insurrection [i.e., Protestantism] $]^{4}$ occurred. The construction of the Middle Ages as golden past ${ }^{5}$ then rather served a rhetorical purpose since it allowed him to denounce his own time all the more. Though justified in motive, Protestantism had, according to Novalis, created an intermediate state of conflict and dispute and laid the ground for an atheistic worldview that reached its pinnacle in XVIII-century Enlightenment. Luther, in mistaking the "spirit" of Christianity and supplanting it with the holy supremacy of the Bible, made religion a matter of philology $y^{6}$. Subsequently, the initial personal hatred against Catholic faith turned into hatred against the Bible, the Christian faith and finally even against religion ${ }^{7}$. This de-deification of the Universe gave rise to a mechanistic and materialistic view of nature in which there was no god but only blind causality. That way, the infinitely creative music of the universe was replaced by the monotonous rattling of an immense mill [...] without architect and miller. ${ }^{8}$. France became the centre of this new "faith" with its priests and mystagogues ${ }^{9}$, i.e., the philosophers of the Enlightenment, for Novalis a cult of its own not at all dissimilar to the old uncritical belief represented by Catholicism. The

"Collected Writings" from 1826. Novalis himself simply spoke of the Europa. For the complicated and problematic publication history of the text cf. M. Zanucchi, Novalis - Poesie und Geschichtlichkeit. Die Poetik Friedrich von Hardenbergs. Paderborn - Munich - Vienna - Zürich 2006, p. 64-67. Citation in this paper follows the Historisch-kritische Ausgabe (HKA) edited by P. Kluckhohn and R. Samuel.

2 Cf. W. Hädecke, Novalis. Biographie, Munich 2011, p. 266. Amongst the participants were Hardenberg's brother Carl, the brothers Schlegel with wife resp. mistress, Ludwig Tieck, Schelling and the natural philosopher and physicist Johann Wilhelm Ritter.

3 One particularly waspish response came from the philosopher Friedrich Wilhelm Joseph Schelling, who wrote a satirical long poem, entitled "Epicurean Confession of Faith of Hans Bristleback" (Epikurisch Glaubensbekenntnis Heinz Widerporstens), in which he specifically attacked Novalis' idealisation of mariolatry and its sensuous character.

4 „die Gemeinheit und Niedrigkeit ihrer Denkungsart [...] lange vor der gewaltsamen Insrurrection stillschweigend aufgehört", trans. by author. Novalis, Die Christenheit oder Europa, 1799, p. 510-511.

„Konstruktion des Mittelalters als goldene Vorzeit", trans by. author, M. Zanucchi, op. cit., s. 70.

6 „Luther behandelte das Christenthum überhaupt willkürlich, verkannte seinen Geist, und führte einen andern Buchstaben und eine andere Religion ein, nämlich die heilige Allgemeingültigkeit der Bibel, und damit wurde leider eine andere höchst fremde irdische Wissenschaft in die Religionsangelegenheit gemischt - die Philologie [...].", trans. by author. Ibidem, p. 512 .

„Der anfängliche Personalhaß gegen den katholischen Glauben ging allmählig in Haß gegen die Bibel, gegen den christlichen Glauben und endlich gar gegen die Religion über.", trans. by author. Novalis, op. cit., p. 515.

8 „machte die unendliche schöpferische Musik des Weltalls zum einförmigen Klappern einer ungeheuren Mühle [...] ohne Baumeister und Müller", trans. by author. Ibidem, p. 515.

9 "Der Enthusiasmus für diese herrliche, großartige Philosophie und insbesondere für ihre Priester und ihre Mystagogen", trans. by author. Ibidem, p. 515. 
French Revolution was thus an ambiguous event: With its Cult of Reason, it was the epitome of this development, centred around a profane ideology that exhausted itself in destruction and negativity, a secular Protestantism ${ }^{10}$ stripped of the last remnants of old Christianity. Such a state could, however, only [be] temporary ${ }^{11}$, because it left man without spiritual orientation. Thereby it became the breeding ground of a renewed faith: True anarchy is the generative element of religion. From the destruction of everything positive it lifts its glorious head as the founder of a new world. ${ }^{12}$ For Novalis, now, it was not just any people to whom this task of renewing European Christendom was historically assigned to, but it was the Germans since they - as the only European people - still possessed the "universality" that was necessary to overcome the prevalent nationalistic and religious dispute.

In his previously published Blüthenstaub, a collection of aphorisms that first appeared in 1798 in the Athenäum, Novalis draws a parallel between Germany and the Roman Empire, arguing that both came into being in just the same way ${ }^{13}$. Our old nationality, he explains, was truly Roman. [...] The instinctive universal politics and tendency of the Romans also exists in the German people. Novalis implicitly draws on the old concept of the Imperial State that serves him as a counter model to the western state nation (Staatsnation). ${ }^{14}$ Like Rome, the - then still existing - "Holy Roman Empire" (that considered itself the direct inheritor of the ancient Imperium) was a multinational state, asserting a universal claim to encompass the whole orbis terrarum resp. the entire occidental Respublica Christiana. Whereas the western countries had lost this "instinctive universal tendency", the Germans, not narrowed by national political interests, still held on to the idea of a united Christian humanity. Only seemingly sarcastically then, Novalis concludes: The best thing that the French have gained in the revolution is a portion of Germanity. ${ }^{15}$

In a fragment later omitted in Blüthenstaub, Novalis further elaborates on this concept of "Germanity". For him, Germans are found everywhere. Germanity, like Romanity or Britannity, is not confined to a particular state - they are general

10 "Frankreich verficht einen weltlichen Protestantismus", trans. by author. Ibidem, p. 518.

11 „nur vorübergehend seyn“, trans. by author. Ibidem, p. 511.

12 „Wahrhafte Anarchie ist das Zeugungselement der Religion. Aus der Vernichtung alles Positiven hebt sie ihr glorreiches Haupt als neue Weltstifterin empor.", trans. by author. Novalis, op. cit., p. 517.

13 „Unsere alte Nationalität, war, wie mich dünkt, echt römisch. [...]. Die instinktartige Universalpolitik und Tendenz der Römer liegt auch im deutschen Volk. Das Beste, was die Franzosen in der Revolution gewonnen haben, ist eine Portion Deutschheit.", trans. by author. Novalis, Vermischte Bemerkungen [Blütenstaub], in: idem, Gesammelte Werke, Ed. by H.J. Balmes. Frankfurt am Main 2008, p. 390-416, here: 403.

14 Cf. F. Meinecke, Weltbürgertum und Nationalstaat. Studien zur Genesis des deutschen Nationalstaates. München - Berlin 1928, p. 70-71. For Novalis, Prussia too was such a "state nation" that he opposed to the German "cultural nation" (Kulturnation).

15 „weil wir auf eben dem Wege wie die Römer entstanden“, trans. by author. Novalis, Vermischte Bemerkungen..., p. 403. 
human characters - which have just become predominantly general here and there. Germanity is true popularity and therefore an ideal. ${ }^{16}$ This universalisation of "Germanity" not only serves him to propagate German cultural superiority. In an almost ingenious way, it also enables him to play off the lack of actual political power as an advantage, since it allowed the Germans to develop their spirituality, thus preparing the ground for the renewal of Christian Europe. Whereas the Great Powers were being consumed by war, speculation and factionalism, the German, Novalis declared, is taking a slow but steady path ahead of the other European countries, thereby educating himself with diligence to be the companion of a higher epoch of culture, and this advance must give him a great superiority over the others in course of time.$^{17}$ In this manner, Novalis equals the task of Germany's "national education" with the fate of all Christian Europe. His European project then, often considered as providing an alternative to national and nationalistic projects $^{18}$, at a closer look reveals itself to be actually a primarily German project.

In the $19^{\text {th }}$ century the Europa widely served as basic model of a romantic-conservative philosophy of history ${ }^{19}$. It could do so because the ideas Novalis propagated met with resonance in the mindset of a great part of his contemporaries. Although, however, the medieval notion of a universal empire remained deeply rooted amongst Germany's intellectual elite for some time, it was eventually replaced with a more "secular" nationalism. Hegel and Fichte were amongst those who declared that the thought of a bygone "universal monarchy" (Universal-Monarchie) must not be allowed to hinder the creation of a German nation state. The idea of a special "Germanity", nevertheless, still proved to be highly adaptable, exactly because it was relatively vague. Thus, A.W. Schlegel could in his Lectures on Literature and Art (Vorlesungen über schöne Literatur und Kunst, 1801-1804) identify Romanticism with universalism and declare that it was the Germans universality that enabled them to willingly renounce their nationalit $y^{20}$, thus becoming the forerunners of a new cultural age.

The most impactful use of this figure of thought, however, was made by Fichte in his (in-) famous Speeches to the German Nation (1807/1808) that widely popularised

16 „Deutsche gibt es überall. Germanität ist so wenig wie Romanität oder Britannität auf einen besondern Staat eingeschränkt - es sind allgemeine Menschencharaktere - die nur hie und da vorzüglich allgemein geworden sind Deutschheit ist echte Popularität und darum ein Ideal.“, trans. by author. Novalis, Vermischte Bemerkungen..., p. 373.

17 „Deutschland geht einen langsamen, aber sichern Gang vor den übrigen europäischen Ländern voraus. Während diese durch Krieg, Spekulation und Parteigeist beschäftigt sind, bildet sich der Deutsche mit allem Fleiß zum Genossen einer höhern Epoche der Kultur, und dieser Vorschritt muss ihm ein großes Übergewicht über die andere[n] im Lauf der Zeit geben.", trans. by author. Novalis, Die Christenheit oder..., p. 519.

18 M. Hurd, Borderland Identities. Territory and Belonging in Central, North and East Europe. Eslöv 2006, p. 111.

19 „Grundmodell einer romantisch-konservativen Geschichtsphilosophie“, trans. by author. H. Kurzke, Novalis. Munich 1988, p. 61.

${ }^{20}$ „sie [die Deutschen] allein verbinden Tiefe mit Universalität, und ihre Nationalität besteht darin, sich derselben willig entäußern zu können.“ (A.W. Schlegel, Vorlesungen über schöne Literatur und Kunst, in: idem, Schriften. Ed. by W. Flemmer. München n. d. [1962], p. 97). 
the idea of a supposed German "originality". For Fichte the German language was an "original language" (Ursprache) that directly linked the German people to the realm of the spirit (Geist) or absolute (Göttliches). ${ }^{21}$ In contrast, French and English were "dead" languages separated from the absolute, and it was from that notion that Fichte rejected the "ideas of 1789", those three infamous words, humanity, popularity, liberality $^{22}$, as he viewed them as artificial abstractions that could bear no meaning in German. Instead, he urged for a "national education" (Nationalerziehung), which represented for him no contradiction to the universalistic goal of the "education of man" (Erziehung zum Menschen), on the contrary: As the German people was for Fichte an "original people" (Urvolk), linked to the original spirit of humanity, such a national education was in his eyes synonymous with the task of educating the entire human individual to be a human individual completely and in every respect ${ }^{23}$.

In the end, the idea that Germany had to fulfil some cultural-religious "mission" in Europe furthered the estrangement of the educated middle-classes from practical politics. Yet, at the same time it gave them a sense of purpose they could cling to the more this estrangement progressed. In this sense, Schelling in 1849, highly suspicious of the previous revolution, remembered Maximilian II. in a letter that the Reformation was the real historical destiny of the German people, its never ending task to not only recognize but also realise over the political unity that was lost with the Reformation the higher unity ${ }^{24}$.

Novalis had ultimately transferred Christian universalism and missionarism into politics, thereby establishing a line of thinking that German nationalism would lastingly incorporate into its mindset, sometimes to a devastating effect. While French and English nationalism evolved from an existing political basis, German

${ }_{21}$ The underlying distinction between „organic” and „mechanic” languages had originally been introduced by Friedrich Schlegel (1806). The concept was then further developed by his brother August Wilhelm who, in 1818, introduced the terms of „analytic” and „synthetic” language in his Observations sur la Langue et la Littérature provençales. Cf. U. Hinrichs, Prolegomena zu einer Theorie des Analytismus I anhand der Sprachen in Ost- und Südosteuropa, in: Die Südosteuropa-Wissenschaft im neuen Jahrhundert. Ed. by U. Hinrichs and U. Büttner, Wiesbaden 2000, p. 83-105, here: 88-89. Fichtes essay "Von der Sprachfähigkeit und dem Ursprung der Sprache" (On the Faculty of Speech and the Origin of Language) (1795), in which he first elaborated on his concept of the original language, may have been of influence for Novalis' own Fichte Studies (Fichte-Studien) (1795/96). Conversely, Fichte's original language as an infinitely generative process certainly shows strong similarities to Novalis' progressive universal poesy (progressive Universalpoesie). Cf. W.A. O’Brien, Novalis. Signs of Revolution. Durham u. London 1995, p. 89-97.

22 „die drei berüchtigten Worte, Humanität, Popularität, Liberalität“, trans. by author. J.G. Fichte, Reden an die deutsche Nation. Ed. with introduction by A. Aichele, Hamburg 2008 [1978], p. 70.

${ }^{23}$ „den ganzen Menschen durchaus und vollständig zum Menschen zu bilden“, J.G. Fichte, op. cit., p. 49, trans. after P. Bishop, Nationalism and Europeanism in German Romantic Literature, in: Nationalism versus Cosmopolitanism in German Thought and Culture, 1789-1914. Essays on the Emergence of Europe. Ed. by M.A. Perkins and M. Liebscher, Lewiston (NY) et. al., p. 93-130, here: 122.

24 „in diesem Ereignis lag die geschichtliche Bestimmung des deutschen Volks, sein nie aufzugebender Beruf, über der politischen Einheit, die durch die Reformation verloren gehen mußte, die höhere nicht bloß zu erkennen, sondern zu verwirklichen“, trans. by author. F.W.J. Schelling, Letter to Maximilian II, Berlin 30th Dec. 1849, in: Schelling. Coll. a. ed. by M. Boenke [= Philosophie Jetzt! Ed. by P. Sloterdijk]. Munich 1995, p. 93-95, here: 94. 
intellectuals lacked such a reference. Instead, the old religiously based Reichsgedanke provided them with an alternative source of tradition that could compensate for the lack of political unity and serve as a counter model to "French atheism" and western nationalism in general. Although the idea of a German "mission" in Europe was gradually detached from its theological roots, it remained a continuous and constitutive element of German national thinking, as was shown in the "Ideas of 1914" in which the notion of a German "culture" as opposed to Western "civilisation" played a pivotal role. Eventually, lines of tradition can be drawn as far as to the National Socialist concepts of Europe that were used to justify the German war efforts as serving the defence of the whole civilised occident (Goebbels, $30^{\text {th }}$ January 1943).

\section{BIBLIOGRAPHY}

Bishop Paul, Nationalism and Europeanism in German Romantic Literature, in: Nationalism versus Cosmopolitanism in German Thought and Culture, 1789-1914. Essays on the Emergence of Europe. Ed. by M.A. Perkins and M. Liebscher, Lewiston (NY).

Fichte Johann Gottlieb, Reden an die deutsche Nation. Ed. with introduction by A. Aichele, Hamburg 2008.

Hädecke Wolfgang, Novalis. Biographie, Munich 2011.

Hinrichs Uwe, Prolegomena zu einer Theorie des Analytismus I anhand der Sprachen in Ost- und Südosteuropa, in: Die Südosteuropa-Wissenschaft im neuen Jahrhundert. Ed. by U. Hinrichs and U. Büttner, Wiesbaden 2000.

Hurd Madeleine, Borderland Identities. Territory and Belonging in Central, North and East Europe. Eslöv 2006.

Kurzke Hermann, Novalis. Munich 1988.

Mähl Joachim, Die Idee des goldenen Zeitalters im Werk des Novalis. Studien zur Wesensbestimmung der frühromantischen Utopie und zu ihren ideengeschichtlichen Voraussetzungen, Heidelberg 1965.

Meinecke Friedrich, Weltbürgertum und Nationalstaat. Studien zur Genesis des deutschen Nationalstaates. München - Berlin 1928.

Novalis, Die Christenheit oder Europa, 1799.

Novalis, Vermischte Bemerkungen [Blütenstaub], in: idem, Gesammelte Werke, Ed. by H.J. Balmes. Frankfurt am Main 2008.

O’Brien William Arctander, Novalis. Signs of Revolution. Durham u. London 1995.

Pikulik Lothar, Frühromantik. Epoche - Werke - Wirkung. München ${ }^{2} 2000$ [1992].

Schelling Friedrich Wilhelm Joseph, Letter to Maximilian II, Berlin 30th Dec. 1849, in: Schelling. Coll. a. ed. by M. Boenke [= Philosophie Jetzt! Ed. by P. Sloterdijk]. Munich 1995.

Schlegel August Wilhelm, Vorlesungen über schöne Literatur und Kunst, in: A.W. Schlegel, Schriften. Ed. by W. Flemmer. München n. d. [1962].

Schulz Gerhard, Novalis. Leben und Werk Friedrich von Hardenbergs, München 2011.

Uerlings Herbert, Das Europa der Romantik. Novalis, Friedrich und August Wilhelm Schlegel, Manzoni, in: Das Europa-Projekt der Romantik und die Moderne. Ansätze zu einer deutsch-italienischen Mentalitätsgeschichte. Ed. by S. Vietta, D. Kemper und E. Spedicato, Tübingen 2015.

Zanucchi Mario, Novalis - Poesie und Geschichtlichkeit. Die Poetik Friedrich von Hardenbergs. Paderborn - Munich - Vienna - Zürich 2006. 